\title{
Yüksek Riskli Kasa Invaze Olmayan Mesane Kanserinde Erken Sistektomi mi yoksa Mesane Koruyucu Tedavi mi Tercih edelim?
}

\author{
Which Treatment Should We Prefer for High-Risk Nonmuscle Invasive Bladder Cancer? \\ Early Cystectomy or Bladder Sparing?
}

\author{
Dr. Ali Furkan Batur1, Dr. Sinan Sözen² \\ ${ }^{1}$ Sincan Devlet Hastanesi, Üroloji Kliniği, Ankara, Türkiye \\ ${ }^{2}$ Gazi Üniversitesi Tıp Fakültesi, Üroloji Anabilim Dalı, Ankara, Türkiye
}

\section{Özet}

Bu yazıda yüksek riskli kasa invaze olmayan mesane kanserlerinin tanımının ayrıntılarıyla yapılması ve progresyon gösterme riskleri bulunanların en yüksek oranda tahmin edilebilmesi için en son bilgilerin irdelenmesi amaçlanmıştır. Ayrıca bu tanının konulduğu hastaların tedavi yönetimlerinin planlanmasına dair en son araştırmaların sonuçlarının değerlendirilmesi yapılmıştır. Günümüzde yüksek riskli kasa invaze olmayan mesane kanserlerinin gerçek tanısı evre ve derecesine göre yapılmaktadır. Eşlik eden diğer faktörlerin riski arttırdığı çeşitli risk değerlendirme araçları ve nomogramlarla kanıtlanmıştır. Yüksek riskli olduğu sonucuna varılan hastalarda intravezikal Basillus Calmette Guerin (BCG) veya radikal sistektomi uygulanması konusu üzerinde günümüzde karşıt görüşler bulunmaktadır. Tanı anında hangi hastaların yüksek riskli olduğunu belirleme konusunda çalışmalar oldukça başarılı olmakla beraber bu hastaları daha iyi ve daha yüksek oranda tahmin edebilmek için ileri araştırmalara ihtiyaç vardır. Özellikle bu araştırmaların, moleküler belirteçlerin de risk belirleme araçları ve nomogramlar içinde belirleyici rol aldığı çok merkezli çalışmalara odaklanması uygun olacaktır. (Üroonkoloji Bülteni 2014;13:93-98)

Anahtar Kelimeler: Kasa invaze olmayan mesane kanseri, yüksek riskli, Basillus Calmette Guerin, sistektomi

\section{Summary}

We aimed to evaluate the recent knowledge about the definiton of highrisk non-muscle- invasive bladder cancer in order to enhance our ability to predict the ones at the highest risk of progression. It was also our aim to evaluate the results of recent research focusing on the best treatment strategies for those patients. Contemporarily, the mainstay definitions of high-risk non-muscle-invasive bladder cancer are based on grade and stage. But, some accompanying factors increasing the risk have been proved through various risk assessment tools and nomograms. However, there are still controversies that exists on the treatment strategy of highrisk patients either with intravesical BCG or radical cystectomy. Although recent studies are succesfully predicting the high-risk patients, future research is needed to predict the high risk patients with acceptable accuracy rate. Particularly, these future researches should concentrate on risk assessment tools and nomograms, including the molecular markers which have definitive roles in large multi-institutional cohorts. (Bulletin of Urooncology 2014;13:93-98)

Key Words: Non-muscle invasive bladder cancer, high-risk, Basillus Calmette Guerin, cystectomy

\section{Giriş}

Mesane kanserleri üriner sistemin en sık görülen malignensileridir (1). Tüm kanserler içerisinde de giderek artan insidansıyla, Avrupa ve Amerika'da değişen oranlarda görülmekle beraber en sık 5.-7. sıralarda görülen kanser tipidir $(1,2)$. Mesane kanserlerinin yaklaşık \%75'i tanı konulduğunda mesanenin mukozasına (Ta) veya submukozası olan lamina propriada (T1)

sınırlı olmakla beraber bunların bir kısmı ilerleyerek kasa invaze olabilmektedir. Yakın zamana kadar Ta ve T1 mesane kanserleri "Yüzeyel Mesane Kanserleri" olarak tanımlanmaktayken, bu grup içerisinden de önemli bir oranda, prognozu çok ciddi seyirli invazif tiplere ilerleyebilen hastalar olduğu tespit edildiği için, bu tanımlama değişmiş ve artık bu grup mesane kanserlerine "Kasa İnvaze Olmayan Mesane Kanserleri (KIOMK)" denilmeye başlanmıştır (3). KiOMK grubu içinde yüksek progresyon ve 
daha sonra da metastaz yapabilme potansiyeline sahip yüksek riskli hastaları belirlemek ve onları daha agresif tedavi etmek, bu hasta grubundaki morbidite ve mortaliteyi önemli oranda azaltabilmektedir. Son zamanlarda bu konuyla ilgili yapılmış çalışmalarda ilginç sonuçlar göze çarpmaktadır. Bunlara göre, tanı anında KIOMK hastaları arasından progresyon gösterenler ve kasa invaze hale gelenlerin prognozu, tanı anında kasa invaze olanlardan belirgin oranda daha kötüdür. Bu bilgi de bize, KIOMK hastalarını en son risk sınıflandırma şemaları ve nomogramlarla değerlendirme zorunluluğunu ve tanı anından itibaren de en uygun ve yeterli tedavi yönetimlerini uygulama mecburiyetini getirmektedir $(4,5)$.

Bu yazıda ürologlar arasında tanısına ve tedavi yönetimine karar verirken sıklıkla ikilemde kalınan yüksek riskli KIOMK tanımının ayrıntılarıyla yapılması ve KIOMK arasında progresyon ve metastaz gösterme riskleri bulunanların en yüksek oranda tahmin edilebilmesi için en son bilgilerin derlenmesi amaçlanmıştır. Ayrıca yüksek riskli KiOMK tanısı konulan hastaların mesane koruyucu veya radikal cerrahi ile tedavi yönetimlerinin planlanmasına ve bu tedavilerin zamanlamalarına dair en güncel bilgiler verilmesi amaçlanmıştır.

\section{Yüksek Riskli Kasa İnvaze Olmayan Mesane Kanseri Tanımı ve Evrelemesi}

Yüksek riskli KIOMK tanımı günümüzde halen tümörün derece ve evresine göre yapılmaktadır. Bu tanımı yapmadan evvel, temel bilgiler ışığında öncelikle sistoskopik bulgusu yüksek riskli KIOMK düşünülen olgularda, yapılan transüretral rezeksiyonda (TUR) mesane perforasyonuna yol açmayacak şekilde ancak muskularis propria tabakasını da içerecek şekilde yapılması gerekliliğini hatırlatmakta fayda bulunmaktadır. Çünkü değişen oranlar verilmekle beraber re-TUR sonrası hastalığın evresi genellikle yükselme eğilimi göstermektedir. Bu açıdan rezeksiyonun ve patolojik değerlendirmenin standardizasyonu şarttır. Bu konu üzerinde yapılmış çalışmalarda ilk TUR materyali muskularis propria içerse dahi re-TUR veya ilk TUR sonrası radikal sistektomide evre yükselmesi oranları \%20-\%30 arasında bulunmuştur $(6,7)$. Patoloji uzmanları arasındaki değişkenliği inceleyen Avrupa Onkolojik Araştırmalar Birliği'nin (EORTC) 1400 hastanın verilerini inceledikleri çalışmalarında ise ilk TUR patolojisi T1G3 transizyonel hücreli karsinom (TCC) olan hastaların sadece \%50'sinin tanısı üzerinde uzlaşılmış ve kalan yarısının ise düşük veya yüksek evreli olduğu tespit edilmiştir (8).

Mesane kanseri tanısı standardize edildikten sonra asıl sorun prognozunun ilk andan itibaren tedavi yönetimine bu kadar bağlı olan yüksek riskli KIOMK grubunu belirleyebilmektir ve bu yüzden son yıllarda çeşitli araştırmacılar bu konunun üzerinde çalışmalar yapmışlardır ve hala da yapmaktadırlar. Yüksek riskli KIOMK hastalarını belirleyebilmek için Amerikan Üroloji Birliği ve Avrupa Üroloji Birliği (EAU) çeşitli risk faktörleri belirlemişlerdir ve özellikle EAU bu konu üzerinde çok yoğun çalışarak EORTC çatısı altında bir takım faktörlere göre hastalığın progresyonu ve rekürrensi ihtimallerini belirleyen skorlama sistemi oluşturmuştur (9). Günümüzde mesane kanserinde yüksek riskli grubu belirlemek için en çok kullanılan skorlama sistemlerinden bir tanesi budur (http:// www.eortc.be/tools/bladdercalculator/) (1). Bu skorlama sistemi; tümör sayısı, boyutu, önceki rekürrens oranı, T kategorisi, eşlik eden karsinoma in-situ (CIS) varlığı ve tümör derecesi olarak 6 adet klinik ve patolojik faktöre dayanılarak oluşturulmuştur (1).

Bahsedilen tablolara ek olarak son yıllarda yüksek riskli KiOMK hastalarını belirlemek için patolojik alt tipler, nomogramlar ve moleküler belirteçlerin de kullanıldığını ve oldukça başarılı sonuçlar verdiklerini çalışma sonuçlarından anlamaktayız (9).

Mesane kanserinin patolojik alt tipleri değerlendirildiği zaman mikropapiller, glandüler, adalı (nested), sarkomatoid ve skuamöz gibi tiplerin daha kötü prognozla ilişkili olduğu bulunmuştur ve dolayısıyla bu patolojik alt tiplere sahip KiOMK hastalarını yüksek riskli gruba dahil etmemiz gerektiği ve buna yönelik tedavi yönetimi yapmamız gerektiği yönünde yayınlar bulunmaktadır $(10,11)$.

Nomogramlara göre riskli grubu belirlemek için yapılan çalışmalar prostat kanserine göre çok daha azdır, ancak Shariat ve ark.'nın KiOMK'de rekürrens ve progresyon ihtimallerini değerlendirdikleri ve 10 merkezden 2500 'ün üzerinde hastanın dahil edildiği nomogram çalışması rekürrensi \%84 ve progresyonu $\% 87$ oranında belirleyerek umut vaat etmiştir. Bu nomogramda enterasan olarak patolojik tümör karakteristiklerinden farklı olarak hasta yaşı ve cinsiyeti, idrar sitolojisi ve tümör belirteçleri (özellikle nükleer matriks protein-22- NMP-22) en doğru sonuçları vermiştir. Bunun dışındaki diğer nomogramlar KIOMK'lerine odaklanmamıştır ve henüz üzerlerinde çalışılması gerekmektedir $(9,12)$.

Gelecekte bütün kanserlerin prognozunu belirlemekte en yüksek güvenilirliğe sahip olabilecek moleküler belirteçler açısından yüksek riskli KIOMK tanısı için de bir takım çalışmalar elbette devam etmektedir. Bu çalışmalarda da önemli mesafeler kat edilmiştir. Özetlemek gerekirse, hücre döngüsünde yer alan p53, p21, p27 ve pRB gibi genlerin miktarında yükselmelerin yüksek riskli KIOMK hastaları ile ilişkili olduğu tespit edilmiştir (13). Bunun yanında fibroblast büyüme faktörü reseptör 3 (FGFR-3) mutasyonları düşük riskli KiOMK ile ilişkili bulunmuş ve yüksek riskli KIOMK'li hastaların sadece \%7'sinde bu mutasyonun olduğu tespit edilmiştir (14). Moleküler belirteçler açısından üriner belirteçlere bir parantez açmak gerekmektedir ki bunlarla ilgili bitmiş ve de devam eden bir çok çalışma bulunmaktadır. Üriner belirteçlerden sadece NMP-22 ile ilgili bazı sonuçlar bulunmakla beraber bu belirteçle de ilgili henüz kesin karar verdirecek çalışma bulunmamaktadır. Bunun haricinde, mesane kanseri tanısında Amerikan yiyecek ve ilaç birliği onayı bulunan BTA ve Urovysionla ilgili yüksek riskli KIOMK belirlemede önemli olduklarına dair güçlü bir delil bulunmamaktadır (15).

\section{Tedavi Yönetimi}

\section{Transüretral Rezeksiyon (TUR) Sonrası Erken Profilaktik} İntravezikal Kemoterapi

Hastanın tanısı sonrası ilk basamakta yapılacaklar konusu üzerinde net bir şekilde uzlaşıya varılmıştır. Öncelikle makroskobik olarak KIOMK düşünülüyorsa ve eğer çok derin rezeksiyon yapılmamışsa, mesane perforasyonu olmamışsa veya hastanın ciddi bir alerjik durumu hikayesi yoksa her hastaya erken dönem intravezikal tek doz kemoterapi uygulanmalıdır. Bu amaçla kullanılan ajanlar mitomisin C (MMC), doksorubisin, epirubisin ve tiotepadır. Aralarında belirgin bir fark olmasa da günümüzde en yaygın kullanım $40 \mathrm{~cm} 3$ salin solüsyonu içerisine $40 \mathrm{mg}$ MMC koyularak uygulanılan tedavidir $(16,17)$. 
İkincil Transüretral Rezeksiyon (re-TUR)

Yeni tanı konulmuş T1G3 TCC varlığında günümüzdeki yaklaşım ilk TUR'dan sonraki 4-6 hafta içerisinde re-TUR yapmak şeklindedir. Bunun nedeni tanı kısmında da bahsedildiği üzere re-TUR'un ilk TUR patoloji sonucunun çoğunlukla da evresini yükseltmesi ve böylece daha doğru bir tanı sağlamasının yanında rezidü tümörü belirleme ve tedavi etme olanağı vermesi ve böylece sağ kalıma katkı sağlamasıdır $(6,7,8)$. Bununla ilgili yapılan önemli bir çalışmada TUR+MMC ile TUR+MMC+re-TUR hastalarının randomize edildiği Divrik ve ark.'nın yaptığı önemli bir çalışmada 3 yıllık rekürrenssiz sağkalım (RSK) oranları \%37'ye \%69 gibi yüksek oranda farkla re-TUR grubu lehine çıkmışır (18). Re-TUR seçeneğinin bir diğer avantajı da prognozun belirlenmesine katkısıdır. Bununla ilgili yapılan bir çalışmada re-TUR'da rezidü T1 hastalık saptanan hastaların $\% 82$ 'sinde 5 yıl içerisinde kas invazyonu geliştiği tespit edilmiştir. Bu önemli veri bize re-TUR'da çıkabilecek rezidü $T 1$ hastalı̆ı̆ın bulunmasının negatif prognostik bir gösterge olduğunu ve bu hastalarda erken radikal sistektomi seçeneğinin her zaman akılda bulundurulması gerektiğini göstermektedir (19).

\section{Mesane Koruyucu Tedavi Seçeneği: İntravezikal Basillus Calmette Guerin'in (BCG) Rolü}

\section{Intravezikal Basillus Calmette Guerin (BCG) Uygulanması ve İdame Tedavisi}

Yüksek riskli KiOMK'lerinde mesane koruyucu tedavi seçeneği intravezikal Basillus Calmette Guerin (BCG) uygulanmasıdır. Uzun zamandır BCG tedavisinin şeması standart 6 haftalık süreçte haftada bir instillasyonlar şeklindeyken yüksek riskli KIOMK'lerinde bu şema rekürrens ve progresyon oranlarının yüksek olmasından dolayı uzun süreli idame tedavi şemasına döndürülmüştür. Cookson ve ark.'nın yaptığı ve 86 yüksek riskli T1G3 hastayı ortalama 184 ay takip ettikleri çalısmalarında \%31 oranında 5 yılda progresyon olduğunu bunlardan 4 hastada 10 yıldan sonra ve 1 hastada da 15 yıldan sonra progresyon gerçekleştiğini tespit etmeleri bu hastaları hiçbir zaman takipten çıkarmamamız gerektiğini ve hayat boyu sistoskopik ve sitolojik takip etmemiz gerektiğini bize hatırlatmaktır (20).

BCG'nin bu hasta grubunda terapotik avantajı kesinlikle kanıtlanmıştır. Shelley ve ark.'nın yapmış oldukları bir derlemede yalnızca TUR ile BCG tedavisinin etkinliği karşılaştırılmış ve 585 hastayı içeren 6 randomize çalışmanın sonuçları ortaya koymuştur ki 12. ay kontrolde adjuvant BCG alanlarda \%26 oranında rekürrens olmuşken bu oran sadece TUR ile tedavi edilenlerde \%51 olarak tespit edilmiştir (21). Yine Slyvester ve ark.'nın yapmış oldukları bir metaanalizde BCG alan hastalarda göreli risk azalması \%27 olarak tespit edilmiştir (22).

Yüksek riskli KiOMK'lerin tedavisinde BCG dişındaki intravezikal ajanların da etkinliği araştırılmış ve BCG belirgin şekilde üstün bulunmuștur. Yine orta ve yüksek riskli hasta gruplarının dahil edildiği 11 çalışmanın metaanalizinde 1421 BCG alan hasta $1328 \mathrm{MMC}$ alan hasta ile karşısaştııılmıştır ve ortalama 26 aylık takip süresi sonrasında adjuvant MMC alan hasta grubunda rekürrens oranı \%46,4 bulunmuşken BCG grubunda bu oran $\% 38,6$ 'dır (23).

BCG tedavisinin en önemli handikapı sık görülen ve hastanın yaşam kalitesini belirgin oranda azaltan yan etkileridir. Bu anlamda MMC belirgin anlamda avantajlıken rekürrens ve progresyon oranlarının fazla olması bu tedavi seçeneğinin sadece BCG'yi tolere edemeyenler ve radikal sistektomiyi istemeyen hastalarla sınırlandırımasına neden olmuştur. Bunu yanında BCG tedavisinin yan etkilerinin azaltılması için doz azaltılmasına gidilmiş olması ve bunun sonucunda RSK ve hastalıksız sağkalım (HSK) oranlarında belirgin azalmalar olduğu tespit edilmiş olması sebebiyle bu yaklaşımdan da özel durumlar haricinde vazgeçilmiştir $(24,25,26)$.

Intravezikal BCG tedavisi başlangıçta 6 haftalık olarak uygulanmasına ve uzun yıllar bu şekilde kullanılmasına rağmen yapılan bir çok çalışmada idame BCG tedavi şemasının etkinliği bu hasta grubunda kanıtlanmıştır. Bu konuda yapılan prospektif randomize bir Güneybatı Onkoloji Grubu (SWOG) çalışmasında Lamm ve ark. bu hasta grubunda idame şemayı ilk 6 haftalık tedaviyi takiben 3 . ve 6 . aylarda $3^{\prime}$ er haftalık instillasyonlar ve ardından da 3 yıl süresince yılda iki defa $3^{\prime}$ er haftalık instillasyonlar şeklinde belirlemişler, RSK ve progresyonsuz sağkalım (PSK) oranları idame tedavisi alan grupta sadece 6 hafta tedavi alan gruba göre belirgin olarak daha iyi olarak tespit ettiklerini yayınlamışlardır (27). Yine Slyvester ve Böhle'nin ayrı ayrı yaptığı metaanaliz sonuçları da bu hasta grubunda idame BCG tedavisini destekler şekildedir $(22,28)$. İdame BCG tedavisinin en önemli handikapı SWOG çalışmasında tedaviye uzun süreli uyumda ciddi eksiklik olmasıdır. SWOG çalışması göstermiştir ki hastaların sadece \%16'sı planlanmış 7 BCG kürünü tamamlamışlardır. Bu çalışmada ayrıca 3 kür tamamlayanların sonuçları ile 4 veya daha fazla kür tamamlayanların sonuçları da karşılaştıııııı̧ ancak istatistiksel olarak anlamlı bir sonuç elde edilememiştir (27).

\section{Basillus Calmette Guerin Tedavisi Geç Rekürrensler}

Öncelikle BCG tedavisi sonrası geç başarısızlık tanımının doğru yapılması gerekmektedir. Illk TUR sonrası altı haftalık BCG'ye yanit vermeyen hastalara BCG refrakter ve BCG sonrası ilk altı ayda rekürrens gelişen hastalara erken BCG başarısızlığı denir ve bu durumların tedavi yönetimi nettir. Bu hastalara radikal sistektomi önerilir. Ancak, BCG tedavisi sonrası ilk altı ay rekürrensi olmayan ancak sonradan rekürrens gelişen hastalara geç BCG başarısızlığı tanısı konulur ve bu hastaların tedavisi üzerinde karşıt görüşler vardır. Bazı ürologlar bu durumda direk radikal sistektomi önerirken bazıları da kurtarma tedavisi olarak 2. BCG kürünü önermektedirler. Bugün için üzerinde görüş birliğine varılmış tedavi yönetimi eğer rekürrens $T a$ veya $C I S$ ise ikinci kür $B C G$ ve eğer rekürrens $T 1 G 3$ ise radikal sistektomidir (29). Kurtarma tedavi seçeneği olarak intravezikal olarak diğer ajanların uygulanımı araştırılmışsa da çok olumlu sonuçlara ulaşılamamamıştır. Bu konu üzerinde yapılan az sayıda çalışmadan bir tanesi olan Brake ve ark.'nın yaptıkları çalışmada BCG tedavisi alan T1 patolojili 126 hastanın 37 tanesinde rekürrens görülmüş ve bu rekürrenslerin 13 tanesi kas invazif olduğu için radikal sistektomi uygulanmıştır. Diğer 24 hastaya tekrarlayan TUR sonrası BCG verilmiş ve $\% 79$ başarı elde edilmiştir. Bu sonuçlar diğer benzer çalışmalar ile desteklenmiştir (30). Soloway ve ark. yüksek riskli KiOMK tanılı ve geç BCG başarııızlığı olmuş olan 214 hasta ile yaptıkları çalışmada 2 . kür BCG verilen hasta grubunda 5 yıllık hastalığa sekonder ölüm oranını \%48 olarak ve kurtarma radikal sistektomi yapılan hastalarda bu oranı \%31 olarak tespit etmişlerdir (29). İkinci kür BCG başarısızlı̆̆ı sonucunda tedavi olarak ne yapalım sorusuna yanıt ise tam olarak bilinmemekle beraber 3. kür BCG'nin 
Batur ve ark.

Yüksek Riskli Kasa Invaze Olmayan Mesane Kanserinde Erken Sistektomi mi yoksa Mesane Koruyucu Tedavi mi Tercih edelim?

başarı oranının \%6'larda olmasından dolayı tedaviyi kabul eden hastalara yaklaşım radikal sistektomi olarak gözükmektedir (31).

\section{Potansiyel İntravezikal Tedavi Seçenekleri}

Intravezikal BCG tedavisinin hayat kalitesini düşüren yan etkilerinden ve radikal sistektominin de yüksek morbiditesinden dolayı bazı alternatif intravezikal tedavi seçenekleri ve uygulama biçimleri çeşitli araştırıcılar tarafından irdelenmiştir. Bununla ilgili önemli çalışmalardan olan Dalbagni ve ark. ile Bartoletti ve ark. BCG refrakter T1G3 ve radikal sistektomiyi reddeden mesane kanserli hastalarda intravezikal gemsitabin tedavisinin etkinliğini araştırmışlardır. Ancak bir yıllık RSK oranları sırasıyla \%21 ve \%13 bulunmuştur ve bu sonuçlar yüksek riskli KIOMK hastalarında intravezikal gemsitabin tedavisinin rutin kullanım için önerilemeyeceği sonucunu ortaya çıkarmıştır $(32,33)$. İntravezikal tedavi seçenekleri ile ilgili umut verici gelişmelerden bir tanesi elektromotif ilaç uygulaması denilen (Electromotive drug administration-EMDA) ve verilen intravezikal tedavinin üretelyal epiteli daha rahat geçip daha derine ilerlemesini sağlayan sistemdir. Bu konu ile ilgili hem BCG hem de MMC araştırılmış ve çalışmanın ilk sonuçları olumlu çıkmıştır. Ancak bu konu üzerinde daha çok hasta sayısını içeren ve uzun dönemli onkolojik sonuçları içeren çalışmaların yapılması gereksinimi aşikardır (34).

\section{Erken Radikal Sistektominin Yeri}

Yüksek riskli KIOMK hastalarında göreceli olarak yüksek rekürrens ve progresyon oranları, son yıllarda bu hasta grubunda erken radikal sistektomiyi daha uygun bir seçenek haline getirmiştir. $\mathrm{Bu}$ hasta gruplarında yapılan erken radikal sistektomilerin tedavi sonuçları çok başarılıdır ancak bir takım dezavantajları da bulunmaktadır. Bu tedavi seçeneğinin avantajlarını ve dezavantajlarını şöyle sıralayabiliriz;

\section{Avantajları}

1. Kür için en kesin seçenektir,

2. \%20-\%30 oranlarında görülen hatalı düşük evreli hasta grubunda uygun tedavi seçeneğidir,

3. Sistektomi, lenfadenektomi yapılmasına olanak sağlayarak hem tanısal hem de terapotik avantaj sağlamaktadır,

4. Tekrarlayan intravezikal tedaviler ve sistoskopi ihtiyacı ortadan kalkarak hasta takibi kolaylaşmaktadır.

\section{Dezavantajları}

1. Sistektominin perioperatif morbidite ve mortalite oranları göz ardı edilemeyeck seviyelerdedir,

2. Yaşam kalitesi üzerine olumsuz etkileri vardır (ancak özellikle ideam BCG tedavisinin de yaşam kalitesi üzerine olan olumsuz etkileri unutulmamalıdır),
3. BCG tedavisi ile olumlu sonuç alınacak $\% 50$ 'lik hasta grubu da fazladan tedavi edilmiş olur.

Radikal sistektominin avantajları ve dezavantajları birlikte değerlendirildiğinde avantajları özellikle onkolojik sonuçlar açısından ağır basmaktadır. Ayrıca son zamanlarda cerrahi tekniklerin gelişmesiyle operasyon süreleri ciddi olarak kısalmakta ve morbidite ile mortalite oranları da azalmaktadır (35). Aslında yazının başlarında belirtilen yüksek riskli hasta grubunda radikal sistektomi kararının verilmesi giderek daha da kolaylaşmaktadır. Burada sorulması ve yanıtlanması gereken asıl soru sistektominin ne kadar erken yapılması gerektiğidir. Bu konu üzerinde son zamanlarda yeni çalışmalar yapılmış ve olabildiğince erken yapılmasının onkolojik sonuçlar açısından daha doğru olduğu sonucu ortaya çıkmıştır. Herr ve ark. 307 yüksek riskli KiOMK hastasını değerlendirdikleri çalışmalarında BCG tedavisini takiben 2 yıldan daha kısa sürede radikal sistektomi olan hastaların HSK oranlarının 2 yıl sonrası olanlara göre çok belirgin olarak yüksek olduğunu göstermişlerdir (36). Benzer şekilde Denzinger ve ark. 105 T1G3 patolojiye sahip ve multifokalite, tümör boyutunun $3 \mathrm{~cm}$ 'den büyük olması ve eşlik eden CIS özelliklerinden 2 veya 3 tanesinin olduğu hasta grubunda ortalama 11,2 ayda erken radikal sistektomi olanlarla radikal sistektomiyi reddeden hastaları karşılaştırmışlardır. Radikal sistektomi olan grupta 10 yıllık HSK \%78 olarak tespit edilmişken diğer grupta bu oran sadece \%51 olarak bulunmuştur (37). Yine Lambert ve ark. da benzer sonuçlara ulaşmışlardır (38) (Tablo 1).

Tüm bu çalışmalar yüksek riskli hastayı en net ve en erken şekilde belirleme gerekliliğini ortaya koymaktadır ve eğer bir KiOMK hastası yüksek riskli olarak kabul edildiyse erken radikal sistektomi seçeneği ciddi olarak değerlendirilmelidir (Tablo 2).

\section{Diğer Tedavi Seçenekleri}

Mesane koruyucu tedavi seçeneklerinden bir tanesi de intravezikal tedaviyle beraber veya tek başına uygulanılan radyoterapi (RT) seçeneğidir. Aslında bu seçenek, mesane kanserli hastalarda çoğunlukla ileri evre hastalarda ağrı ve kanamanın palyasyonu için kullanılmaktadır. Primer tedavi seçeneği olarak RT çok az merkezde değerlendirilmektedir. Bu merkezlerde de hasta diğer tedavileri reddediyorsa primer RT düşünülmektedir. Weiss ve ark.'nın retrospektif olarak yaptıkları çalışmada yüksek riskli KiOMK hastlarında RT'nin KT ile birlikte uygulandığı hastalarda sırasıyla \%29 ve \%71 gibi olumlu 10 yıllık PSK ve HSK oranları saptamışlardır. Bu hastaların yan etki bakımından da tatmin olduklarını da tespit etmişlerdir (39). Bu konu üzerinde yapılmış en büyük randomize çalışmada Harland ve ark. RT'yi gözlem veya intravezikal MMC/BCG ile karşılaştırdıklarında HSK, PSK ve genel sağ kalım oranlarında herhangi bir fark saptamamışlardır.

\begin{tabular}{|c|c|c|c|c|c|c|c|c|}
\hline Çalışma & $\begin{array}{l}\text { Hasta } \\
\text { sayısı }\end{array}$ & $\begin{array}{l}\text { İzlem süresi } \\
\text { (ay) }\end{array}$ & $\begin{array}{l}\text { BCG } \\
\text { Öyküsü \% }\end{array}$ & $\begin{array}{l}\text { Yüksek } \\
\text { evreleme \% }\end{array}$ & $\begin{array}{l}\operatorname{Ln}(+) \\
\%\end{array}$ & $\begin{array}{l}\text { Rekürrens } \\
\%\end{array}$ & HSK \% & TSK \% \\
\hline Herr ve ark. (36) & 35 & B & 100 & B & B & $B$ & 92 & B \\
\hline Denzinger ve ark. (37) & 54 & 61 & 0 & 26 & B & $B$ & 78 & $B$ \\
\hline Lambert ve ark. (38) & 104 & B & 44 & 40 & B & 48 & 93 & 87 \\
\hline Bianco ve ark. (35) & 66 & 48 & 27 & 27 & 9 & 78 & 78 & B \\
\hline Gupta ve ark. (35) & 167 & 34 & 44 & 50 & 18 & 29 & 92 & 69 \\
\hline
\end{tabular}


Batur ve ark.

Yüksek Riskli Kasa Invaze Olmayan Mesane Kanserinde Erken Sistektomi mi yoksa Mesane Koruyucu Tedavi mi Tercih edelim?

\begin{tabular}{|l|}
\hline $\begin{array}{l}\text { Tablo 2. Çeşitli çalışmalardan derlenen KiOMK hastalarda yüksek } \\
\text { risk faktörleri (35) }\end{array}$ \\
\hline Eşlik eden CIS varlığı \\
\hline Multifokalite \\
\hline Eşlik eden hidronefroz varlığı \\
\hline Tümörün derinliği (T1a vs T1b) \\
\hline Re Tur'da T1 varlığı \\
\hline Tümör boyutunun 3 cm'den büyük olması \\
\hline Yüzeyel prostatik üretra rekürrensi \\
\hline Tanı anında prostatik üretrada T1G3 ve CIS TCC bulunması \\
\hline Lenfavasküler invazyon varlığı \\
\hline Non-fonksiyone mesane \\
\hline
\end{tabular}

Sonuçta da potansiyel toksisite, maliyet etkinlik değerlendirmesi ve rutin uygulanılan intravezikal tedavi seçeneklerine göre belirgin bir üstünlüğü olmaması sebebiyle RT'yi primer önerilen bir seçenek olarak değerlendirmemişlerdir (40).

\section{Sonuç}

Mesane kanserleri arasında tanı ve tedavisinde en çok ikileme düşülen grup KIOMK içinden yüksek riskli olanlardır. Bu grupta hangi hastaların yüksek riskli olduğunu belirlemek, uygun tedavi yaklaşımını göstermek açııından hayati öneme sahiptir. Günümüzde bu hasta grubundaki tedavi seçenekleri öncelikli olarak intravezikal BCG tedavisi ile radikal sistektomidir. Bu derlemede en son bilgiler ışığında yüksek riskli hasta grubunu en yüksek oranda tahmin edebilmeyi sağlayacak olan faktörler ve durumlara göre en uygun tedavi alternatifleri tartışımıştır. Yapılan değerlendirmeler neticesinde belli risk faktörleri üzerinde uzlaşıya varıldığı tespit edilmekle beraber bu konu üzerinde katedilecek uzun bir yol olduğu sonucuna ulaşılmıştır. Özellikle moleküler belirteçler üzerinde yapılacak daha ayrıntılı ve ileri çalışmalar progresyon açısından en riskli grubu belirlemek konusunda aydınlatıcı olacaktır.

\section{Kaynaklar}

1. Babjuk $M$, Böhle A, Burger $M$, et al. EAU guidelines on Non-muscleinvasive bladder cancer (Ta, $\mathrm{T} 1$ and $\mathrm{CIS}$ ). Edition presented at the EAU Annual Congress Stockholm 2014. ISBN:978-90-79754-65-6.

2. Siegel R, Naishadham D, Jemal A. Cancer statistics. CA: Cancer J Clin 2012;62:1029.

3. Bedük Y. Mesane tümörleri, Ürogenital tümörler, 16.bölüm. Temel Üroloji 4. baskı. Editörler: Anafarta K, Arıkan N, Bedük Y. Güneş Tıp Kitabevi, İstanbul, 2011:774-792.

4. Van den Bosch S, Alfred Witjes J. Long-term cancer-specific survival in patients with high-risk, nonmuscle-invasive bladder cancer and tumour progression: a systematic review. Eur Urol 2011;60:493-500.

5. Schrier BP, Hollander MP, van Rhijn BW, et al. Prognosis of muscleinvasive bladder cancer: difference between primary and progressive tumours and implications for therapy. Eur Urol 2004;45:292-296.

6. Babjuk M, Oosterlinck $W$, Sylvester $R$, et al. EAU guidelines on nonmuscle invasive urothelial carcinoma of the bladder, the 2011 update. Eur Urol 2011;59:997-1008.
7. Shapur NK, Katz R, Pode D, et al. Is radical cystectomy mandatory in every patient with variant histology of bladder cancer. Rare Tumors 2011;3:e22.

8. Kamat AM, Dinney CP, Gee JR, et al. Micropapillary bladder cancer: a review of the University of Texas M. D. Anderson Cancer Center experience with 100 consecutive patients. Cancer 2007;110:62-67.

9. Porten SP, Cooperberg MR. High-risk nonmuscle invasive bladder cancer: definition and epidemiology. Curr Opin Urol 2012;22:385-389.

10. Spaliviero M, Dalbagni G, Bochner BH, et al. Clinical Outcome of Patients with T1 Micropapillary Urothelial Carcinoma of the Bladder. J Urol 2014. pii:S0022-5347(14)02824-02829.

11. Ishida M, Iwai M, Yoshida K, et al. Sarcomatoid carcinoma with small cell carcinoma component of the urinary bladder: a case report with review of the literature. Int J Clin Exp Pathol 2013;6:1671-1676.

12. Shariat SF, Zippe C, Ludecke G, et al. Nomograms including nuclear matrix protein 22 for prediction of disease recurrence and progression in patients with $\mathrm{Ta}, \mathrm{T} 1$ or $\mathrm{CIS}$ transitional cell carcinoma of the bladder. J Urol 2005;173:1518-1525.

13. Shariat SF, Ashfaq R, Sagalowsky Al, et al. Predictive value of cell cycle biomarkers in nonmuscle invasive bladder transitional cell carcinoma. J Urol 2007; 177:481-487.

14. Hernandez S, Lopez-Knowles E, Lloreta J, et al. Prospective study of FGFR3 mutations as a prognostic factor in nonmuscle invasive urothelial bladder carcinomas. J Clin Oncol 2006;24:3664-3671.

15. Shariat SF, Marberger MJ, Lotan Y, et al. Variability in the performance of nuclear matrix protein 22 for the detection of bladder cancer. J Urol 2006;176:919-926.

16. Sylvester RJ, OosterlinckW, van der Meijden AP. A single immediate postoperative instillation of chemotherapy decreases the risk of recurrence in patients with stage $\mathrm{Ta} \mathrm{T} 1$ bladder cancer: a metaanalysis of published results of randomized clinical trials. J Urol 2004; 171:2186-2190.

17. Berrum-Svennung I, Granfors T, Jahnson S, et al. A single instillation of epirubicin after transurethral resection of bladder tumors prevents only small recurrences. J Urol 2008;179:101-105.

18. Divrik T, Yildirim $U$, Eroglu AS, et al. Is a second transurethral resection necessary for newly diagnosed pT1 bladder cancer? J Urol 2006;175:1258-1261.

19. Herr HW, Donat SM, Dalbagni G. Can restaging transurethral resection of T1 bladder cancer select patients for immediate cystectomy? J Urol 2007; 177:75-79.

20. Cookson MS, Herr HW, Zhang ZF, et al. The treated natural history of high risk superficial bladder cancer: 15-year outcome. J Urol 1997; 158:62-67.

21. Shelley MD, Court JB, Kynaston H, et al. Intravesical bacillus CalmetteGuerin in Ta and T1 bladder cancer. Cochrane Database Syst Rev 2000:CD001986.

22. Sylvester RJ, van der Meijden AP, Lamm DL. Intravesical bacillus Calmette-Guerin reduces the risk of progression in patients with superficial bladder cancer: a meta-analysis of the published results of randomized clinical trials. J Urol 2002;168:1964-1970.

23. Bohle A, Jocham D, Bock PR. Intravesical bacillus Calmette-Guerin versus mitomycin $C$ for superficial bladder cancer: a formal metaanalysis of comparative studies on recurrence and toxicity. J Urol 2003;169:90-95.

24. Cheng CW, Ng MT, Chan SY, Sun WH. Low dose BCG as adjuvant therapy for superficial bladder cancer and literature review. ANZ J Surg 2004; 74:569-572.

25. Martinez-Pineiro JA, Flores $\mathrm{N}$, Isorna $\mathrm{S}$, et al. Long-term follow-up of a randomized prospective trial comparing a standard $81 \mathrm{mg}$ dose of intravesical bacille Calmette-Guerin with a reduced dose of $27 \mathrm{mg}$ in superficial bladder cancer. BJU Int 2002;89:671-680. 
Batur ve ark.

Yüksek Riskli Kasa İnvaze Olmayan Mesane Kanserinde Erken Sistektomi mi yoksa Mesane Koruyucu Tedavi mi Tercih edelim?

26. Yoneyama T, Ohyama C, Imai A, et al. Low-dose instillation therapy with bacille Calmette-Guerin Tokyo 172 strain after transurethral resection: historical cohort study. Urology 2008;71:1161-1165.

27. Lamm DL, Blumenstein BA, Crissman JD, et al. Maintenance bacillus Calmette-Guerin immunotherapy for recurrent TA, T1 and carcinoma in situ transitional cell carcinoma of the bladder: a randomized Southwest Oncology Group Study. J Urol 2000;163:1124-1129.

28. Bohle A, Bock PR. Intravesical bacille Calmette-Guerin versus mitomycin $C$ in superficial bladder cancer: formal metaanalysis of comparative studies on tumor progression. Urology 2004;63:682-686.

29. Soloway MS, Sofer M, Vaidya A. Contemporary management of stage T1 transitional cell carcinoma of the bladder. I Urol 2002;167:1573-1583.

30. Brake $M$, Loertzer $H$, Horsch R, Keller $H$. Long-term results of intravesical bacillus Calmette-Guerin therapy for stage $\mathrm{T} 1$ superficial bladder cancer. Urology 2000;55:673-678.

31. Nieder AM, Brausi M, Lamm D, et al. Management of stage $T 1$ tumors of the bladder: International Consensus Panel. Urology 2005;66:108-125.

32. Dalbagni G, Russo P, Bochner B, et al. Phase II trial of intravesical gemcitabine in bacille Calmette-Guerin-refractory transitional cell carcinoma of the bladder. J Clin Oncol 2006;24:2729-2734.

33. Bartoletti R, Cai T, Gacci M, et al. Intravesical gemcitabine therapy for superficial transitional cell carcinoma: results of a Phase II prospective multicenter study. Urology 2005;66:726-731.
34. Di Stasi SM, Giannantoni A, Giurioli A, et al. Sequential BCG and electromotive mitomycin versus BCG alone for high-risk superficial bladder cancer: a randomised controlled trial. Lancet Oncol 2006;7:43-51.

35. Kulkarni GS, Hakenberg OW, Gschwend JE, et al. An updated critical analysis of the treatment strategy for mewly diagnosed high-grade T1 (previously T1G3) bladder cancer. Eur Urol 2010;57:60-70.

36. Herr HW, Sogani PC. Does early cystectomy improve the survival of patients with high risk superficial bladder tumors? J Urol 2001;166:1296-1299.

37. Denzinger S, Fritsche H-M, Otto W, et al. Early versus deferred cystectomy for initial high-risk pT1G3 urothelial carcinoma of the bladder: do risk factors define feasibility of bladder-sparing approach? Eur Urol 2008;53:146-152.

38. Lambert EH, Pierorazio PM, Olsson CA, et al. The increasing use of intravesical therapies for stage T1 bladder cancer coincides with decreasing survival after cystectomy. BJU Int 2007;100:33-36.

39. Weiss C, Wolze C, Engehausen DG, et al. Radiochemotherapy after transurethral resection for high-risk $\mathrm{T} 1$ bladder cancer: an alternative to intravesical therapy or early cystectomy? J Clin Oncol 2006;24:2318-2324.

40. Harland SJ, Kynaston $\mathrm{H}$, Grigor K, et al. A randomized trial of radical radiotherapy for the management of pT1G3 NXM0 transitional cell carcinoma of the bladder. J Urol 2007;178:807-813. 